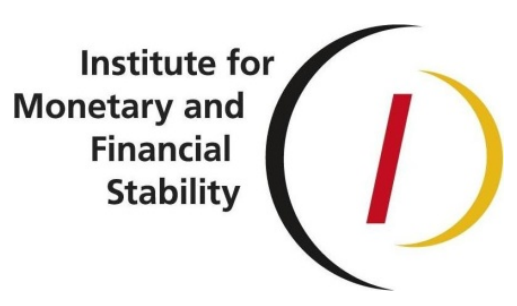

ROMAN INDERST

\title{
Misselling (Financial) Products: The Limits for Internal Compliance
}

Institute for Monetary and Financial Stability

JOHANN WOLFGANG GOETHE-UNIVERSITÄT FRANKFURT AM MAIN 
Prof. Dr. Helmut Siekmann (HRSg.)

INSTITUTE FOR MONETARY AND FINANCIAL STABILITY

PROFESSUR FÜR GELD-, WÄHRUNGS- UND NOTENBANKRECHT JOHANN WOLFGANG GOETHE-UNIVERSITÄT

GRÜNEBURGPLATZ 1

60629 FRANKFURT AM MAIN

TELEFON: (069) $798-34014$

TELEFAX: (069) $798-33913$

E-MAIL: GELD-UND-WAEHRUNG@IMFS-FRANKFURT.DE 


\section{ROMAN INDERST}

\section{Misselling (Financial) Products: The Limits for Internal Compliance}




\title{
Misselling (Financial) Products: The Limits for Internal Compliance
}

\author{
Roman Inderst*
}

September 2008

\begin{abstract}
This paper considers a firm that has to delegate to an agent, such as a mortgage broker or a security dealer, the twin tasks of approaching and advising customers. The main contractual restriction, in particular in light of related research in Inderst and Ottaviani (2007), is that the firm can only compensate the agent through commissions. This standard contracting restriction has the following key implications. First, the firm can only ensure internal compliance to a "standard of sales", in terms of advice for the customer, if this standard is not too high. Second, if this is still feasible, then a higher standard is associated with higher, instead of lower, sales commissions. Third, once the limit for internal compliance is approached, tougher regulation and prosecution of "misselling" have (almost) no effect on the prevailing standard. Besides having practical implications, in particular on how to (re-)regulate the sale of financial products, the novel model, which embeds a problem of advice into a framework with repeated interactions, may also be of separate interest for future work on sales force compensation.
\end{abstract}

JEL Classification: D18 (Consumer Protection), D83 (Search; Learning; Information and Knowledge), M31 (Marketing), M52 (Compensation and Compensation Methods and Their Effects).

*University of Frankfurt and LSE. E-mail: inderst@finance.uni-frankfurt.de. 


\section{Introduction}

Inderst and Ottaviani (IO 2007) develop a model of "misselling" through agents. There, a firm must hire an agent, such as a salesperson or a broker, both to approach customers and to provide advice on how suitable the product is, given a customer's specific needs. ${ }^{1}$ Even when the firm wants to comply to a certain standard at the advice stage, thus advising customers only if the product is "sufficiently" suitable, this still has to be enforced vis-á-vis the firm's agents. The main application of this model is to financial retail products, such as investment funds, pensions, mortgages, or insurance products. ${ }^{2}$

Despite the internal agency problem, in IO (2007) the firm can, however, still ensure compliance to any standard that it finds optimal to set. This is achieved by paying the agent a sufficiently high rent, which comes in the form of a basic (flat) wage. In some industries and, in particular, when independent agents such as brokers and dealers are used, such fixed payments are rare, while additional incentives for the agent may come from the repeated interaction, i.e., the threat of severing the business relationship. On a theoretical level, such a limit to contracting has long been recognized in the financial contracting literature, where it is argued that such "fixed payments" would swamp the firm with the "wrong" applicants-i.e., in the language of the present model, applicants who are unable to attract customers and are thus planning to have a "quiet life". ${ }^{3}$

A key result of this short paper is to point to the following policy implication of such a contractual restriction: the inability of the firm, given its internal agency problem, to implement a standard of sales above a certain threshold. Making the firm vicariously liable for the agent's advice and imposing ever higher penalties in case of alleged "unsuitable selling" (or "misselling") may then be largely ineffective, though it could impose high costs on regulators, the legal system, and the firm.

From a more theoretical perspective, the paper studies a model in the spirit of the "efficiency wage" literature (e.g., Shapiro and Stiglitz (1984)), with the additional feature

\footnotetext{
${ }^{1}$ The agency perspective is a key difference to the large literature on credence and experience goods, following Darby and Karni (1973).

${ }^{2}$ At the time of writing this paper, arguably the most salient case is that of subprime mortgages in the US. According to some observes, customers may often have been ill-advised to take out "jumbo mortgages", which lead to subsequent default and foreclosure, once repayment obligations switched from low teaser rates to much higher rates.

${ }^{3}$ The financial contracting literature sometimes refers to these agents as "fly-by-night operators" (cf. Rajan (1992)).
} 
that the firm's agent has two tasks to perform, but the firm has only one instrument at its disposal: the sales commission. For the purpose of our analysis, we also abstract from the possibility to write long-term contracts that are contingent on the history of past performance. ${ }^{4}$ As is standard, this can be justified on the grounds that the resulting "bond" that the agent would thereby post may not be feasible, given that it would induce opportunistic behavior by the firm. From a more applied perspective, the modelling framework may also be of interest to the large literature on salesforce competition (e.g., Basu et al. (1985)). ${ }^{5}$ With respect to the application to retail financial products, this paper and IO (2007) follow Bolton et al. (2007), which also considers the role of advice, albeit without the internal agency problem that is at the core of the present analysis.

\section{Limits to Compliance}

A firm (the principal) can sell in each period $t \in\{1, \ldots, \infty\}$ a single product through an agent. Both parties are risk neutral and discount future payoffs by some common discount factor $0<\delta<1$. The agent is protected by limited liability and has a reservation value of zero. In each period, by exerting only privately observed effort at disutility $c>0$ the agent contacts a potential customer with probability $\mu>0$. Whether a customer was contacted or not is also the agent's private information. The agent then advises the customer on whether the good is suitable for him or not. For this purpose, the agent privately observes the probability that the product is ultimately suitable for the respective customer: $q \in[0,1]$, which is distributed according to $G(q)$ with density $g(q)>0 .{ }^{6}$ Denote $\widehat{q}:=\int_{0}^{1} q g(q) d q$, which is the ex-ante likelihood with which the product is suitable for any given customer at time $t$.

For the purpose of the present analysis, we abstract from the communication game between the agent and the customer, supposing that, first, the customer always follows the agent's advice and that, second, there is an exogenous price $p$ at which the product is sold. The price $p>0$ exceeds the firm's cost, which is normalized to zero. In IO (2007), $p$ is determined endogenously, based on customers' rational beliefs about the agent's

\footnotetext{
${ }^{4}$ Cf. Bolton and Dewatripont (2005, chapter 10) for a detailed account of this large literature.

${ }^{5}$ The underlying multi-task agency problem follows Holmström and Milgrom (1991) and, more closely, Dewatripont and Tirole (1999).

${ }^{6}$ See IO (2007) for how the (conditional) probability $q$ can be backed out from some signal-generating technology.
} 
communication strategy. Adding this feature to the present model would not alter results in any way. Moreover, the specific case where $p$ is exogenous may fit particular applications, e.g., to health care, where the price may be either regulated or negotiated and paid for by a third party (e.g., the insurer).

As discussed in the Introduction, in contrast to IO (2007) we only allow for positive payments that are made if a sale was concluded, namely through paying some commission or fee $f \geq 0$. This can also not be made contingent on some post-sale signal that the firm observes, given that this is not verifiable. We suppose that, say through some internal review process that checks a fraction $\gamma$ of sales, such a signal reveals the customer's type (i.e., the suitability of the purchase), but is only correct with probability $\varphi>0.5$. For simplicity, set $\gamma=1 .^{7}$ The firm can replace the agent at the end of each period at zero cost. This makes it credible to hire or fire the agent conditional on the outcome of the check. After a bad signal on the suitability, $b$, the agent is fired with probability $\eta .{ }^{8}$ We let the firm choose $(f, \eta)$ to maximize its profits.

The assumptions that we made so far regarding what is observable and what can be contracted on allows us to focus squarely on the dual role of the sales commission $f$, which we explore next. Provided that some choice of $(f, \eta)$ gives the agent sufficient incentives to exert effort in any given period, we ask first about the agent's optimal decision rule when advising a customer. Given stationarity of the problem, we can denote the agent's expected utility at the beginning of each period by $U$. When observing some $q$, the agent will only advise the customer to purchase if

$$
f \geq \eta[\varphi[1-q]+(1-\varphi) q] \delta U
$$

which captures the trade-off between earning $f$ and the increased risk of losing his continuation utility. Holding $f$ and $U$ fixed, (1) generates a cutoff $q^{*}$, such that it is only satisfied for values $q \geq q^{*}$. If this cutoff is interior, we have that

$$
q^{*}=\frac{1}{2 \varphi-1}\left[\varphi-\frac{f}{\eta \delta U}\right] \text {. }
$$

Otherwise, the agent would either never or always want to advise the customer to purchase. We capture the latter two cases by setting either $q^{*}=0$ (in case $f \geq \eta \varphi \delta U$ ) or $q^{*}=1$ (in

\footnotetext{
${ }^{7}$ The following setting differs somewhat from IO (2007). There, given the additional complexity of the model, only a simpler monitoring technology was considered.

${ }^{8}$ Firing the agent with positive probability after no sale was made will not be in the firm's interest. Likewise, it will not be optimal to fire the agent after a good signal on suitability, $g$, was revealed.
} 
case $f \leq \eta(1-\varphi) \delta U) .{ }^{9}$ Note, however, that $U$ is endogenous and will, as discussed next, also depend on the chosen $q^{*}$.

In the present section, we are concerned with the firm's internal agency problem alone, i.e., the firm's problem to induce effort and to implement a given "standard of advice": $q^{*}$. The question of what is optimal for the firm, taking into account its own profits from a sale, will be addressed subsequently.

Suppose that there is an interior cutoff $q^{*}$ as in (2). From stationarity and using $u:=\mu f\left[1-G\left(q^{*}\right)\right]-c$ for the agent's expected per-period utility, provided that the agent exerts effort and applies the standard $q^{*}$, we have that

$$
U=\frac{u}{1-\delta+\delta \mu \eta \int_{q^{*}}^{1}[\varphi[1-q]+(1-\varphi) q] g(q) d q} .
$$

(Cf. the proof of Lemma 1 for more details.) Intuitively, the expected utility of the agent is strictly increasing in $f$. Hence, when considering condition (2), there are thus two conflicting forces that affect the prevailing standard $q^{*}$ : A higher $f$ increases the agent's instant benefits from a sale, but it also increases the value that he puts at risk, namely $\delta U$. We explore this tension first, namely in Lemmas 1 and 2, before fully characterizing the equilibrium outcome. Both Lemmas 1 and 2 will thus, for the time being, build on the presumption that for the considered set of values $(f, \eta)$ there exists a unique equilibrium standard $q^{*}$, satisfying (2).

Lemma 1 A marginal increase in the sales commission $f$ leads to an increase, rather than a decrease, in the lending standard if

$$
\int_{q^{*}}^{1}\left[q-q^{*}\right] g(q) d q>\frac{1}{\eta} \frac{1}{\mu} \frac{1-\delta}{\delta} \frac{1}{2 \varphi-1} .
$$

Instead, if the converse of (4) holds strictly, then the standard decreases.

Proof. To first derive (3) more explicitly, we use $r(q):=\eta[\varphi[1-q]+(1-\varphi) q]$, such that (2) can be expressed as $r\left(q^{*}\right)=\frac{f}{\delta U}$. From stationarity, we have next

$$
U=\delta U\left[(1-\mu)+\mu G\left(q^{*}\right)\right]+\mu \int_{q^{*}}^{1}[f+[1-r(q)] \delta U] g(q) d q-c,
$$

\footnotetext{
${ }^{9}$ Technically speaking, (2) represents the solution to the agent's Bellman equation. Note that the realizations $q=0$ and $q=1$ are zero-probability events.
} 
which uses, in particular, that no purchase is made with probability $(1-\mu)+\mu G\left(q^{*}\right)$. Substituting $u$ yields expression (3). Note next that, using optimality of $q^{*}$, we have that

$$
\frac{d U}{d f}=\frac{\partial U}{\partial f}=\frac{\mu\left[1-G\left(q^{*}\right)\right]}{1-\delta+\delta \mu \int_{q^{*}}^{1} r(q) g(q) d q} .
$$

Implicit differentiation of $r\left(q^{*}\right) \delta U-f=0$ from (2) yields next

$$
\frac{d q^{*}}{d f}=-\frac{1}{\delta U r^{\prime}\left(q^{*}\right)}\left[r\left(q^{*}\right) \delta \frac{\partial U}{\partial f}-1\right]
$$

which from $r^{\prime}\left(q^{*}\right)<0$ is thus positive if and only if $r\left(q^{*}\right) \delta \frac{\partial U}{\partial f}>1$. After substitution from (5), this yields (4). Q.E.D.

From Lemma 1, the effect that a change in $f$ has on the equilibrium standard $q^{*}$ depends thus on condition (4). There are two key observations to be made. First, an increase in $f$ can push up the standard, even though the agent's contemporaneous benefits from selling increase. Second, this works, however, only at low values of $q^{*}$ that still satisfy condition (4). In fact, values of $q^{*}$ where condition (4) does not hold are thus not feasible.

Lemma 2 Suppose

$$
\frac{1}{\eta} \frac{1}{\mu} \frac{1-\delta}{\delta} \frac{1}{2 \varphi-1}<\widehat{q}
$$

holds. Then there exists $0<\bar{q}<1$ satisfying

$$
\int_{\bar{q}}^{1}[q-\bar{q}] g(q) d q=\frac{1}{\eta} \frac{1}{\mu} \frac{1-\delta}{\delta} \frac{1}{2 \varphi-1}
$$

such that it is only feasible to implement a standard $q^{*}$ that satisfies $q^{*} \leq \bar{q}$. The boundary $\bar{q}$ is higher in case:

i) the one-shot agency problem is less severe, as $\mu$ and $\varphi$ are higher;

ii) the agent is more patient, as $\delta$ is higher;

iii) or the agent is fired with a higher probability $\eta$ after a bad signal.

In case (7) does not hold, then no positive standard $q^{*}>0$ can be achieved.

Proof. Observe first that $\int_{q^{*}}^{1}\left[q-q^{*}\right] g(q) d q=\widehat{q}$ holds for $q^{*}=0$. The upper boundary $\bar{q}$ follows immediately from rewriting condition (4). The comparative analysis in i)-iii) follows, in turn, after noting that the left-hand side of (8) is strictly decreasing in $\bar{q}$. Q.E.D. 
To complete the analysis in this Section we have to fully characterize the equilibrium for given choices $(f, \eta)$. For this we have also to take into account that if $f$ is too low, then the agent will not work. In fact, effort is only privately optimal for the agent in case $u \geq 0$, where $u$ depends, however, also on $q^{*}$.

Proposition 1 For given $(f, \eta)$, we have the following equilibrium characterization: i) If $c>\mu f$, then no effort will be exerted; ii) If $c=\mu f$, then there exist multiple equilibria in which either no effort is exerted or effort is exerted and the standard $q^{*}=0$ is chosen; iii) if $c<\mu f$, then effort is exerted and the following cases apply:

- In case condition (7) holds together with

$$
f \geq c \frac{\delta \eta \varphi}{\delta \mu(2 \varphi-1) \eta \widehat{q}-(1-\delta)}
$$

then there exists a unique equilibrium that leads to an interior cutoff $0<q \leq \bar{q}$.

- If either (7) or (9) do not hold, then $q^{*}=0$.

Proof. We ask first when there exists an equilibrium with $0<q^{*} \leq \bar{q}$. From our previous observations, for given $(f, \eta)$ a necessary and sufficient condition for an equilibrium, as characterized by some values for $q^{*}$ and $U$, is that the following conditions hold jointly. First, to ensure that effort is exercised, it must hold that $u \geq 0$. Second, $q^{*}$ and $U$ must jointly satisfy (2) and (3), which holds if

$$
\psi\left(q^{*}\right):=\delta \mu f\left[\int_{q^{*}}^{1}\left[r\left(q^{*}\right)-r(q)\right] g(q) d q\right]-f(1-\delta)-c \delta r\left(q^{*}\right)=0 .
$$

Note next that $\psi^{\prime}\left(q^{*}\right)<0$ holds if and only if $c<\mu f\left[1-G\left(q^{*}\right)\right]$, i.e., if and only if $u>0$. Together with $\psi(1)<0$, we thus have that for $c>\mu f$ there is no value $q^{*}$ satisfying $\psi\left(q^{*}\right)=0$, while for $c<\mu f$ any such value must be unique. In the latter case, such a value also exists if $\psi(0)>0$ and thus after, some transformations, if

$$
f[\delta \mu(2 \varphi-1) \eta \widehat{q}-(1-\delta)]>c \delta \eta \varphi
$$

Condition (11) holds in turn only if two conditions are jointly satisfied: conditions (7) and (9). To conclude the proof, the cases where $q^{*}=0$ can be an equilibrium are immediate from the previous arguments. Q.E.D. 


\section{Optimal Standard}

When making a sale, the firm realizes the profit $p-f$, which is net of the agent's fee. If the firm does not care about the customer's utility, i.e., whether the product is suitable or not, then the firm's optimal compensation contract is immediate: It chooses $f=c / \mu$, thereby inducing $q^{*}=0$, whenever $p>c / \mu$, while for $p<c / \mu$ it is clearly unprofitable to operate. As in IO (2007), we suppose now that a customer who bought an unsuitable product imposes on the firm a cost $\rho>0$ (e.g., through loss of reputation or the actions of a regulator or courts). We further suppose that it is indeed optimal for the firm to operate. The firm's discounted profits are, for given $(f, \eta)$ and with corresponding $q^{*}$, obtained from ${ }^{10}$

$$
\pi=\frac{1}{1-\delta} \mu \int_{q^{*}}^{1}[p-f-(1-q) \rho] g(q) d q .
$$

Note that when the firm implements $q^{*}=0$ and thus chooses $f=c / \mu$, the agent does not realize any rent. At any higher $q^{*}$, the agent realizes a strictly positive rent $U>0$. From Proposition 1, a strictly positive standard can only be obtained if condition (7), which is only on the primitives and on $\eta$, holds. Moreover, in this case $f$ must exceed (9). From Lemma 1, any further increase results in a strictly higher $q^{*}$, albeit not beyond $\bar{q}$. In fact, the marginal impact that $f$ has on $q^{*}$ goes to zero as $q^{*} \rightarrow \bar{q}$. While the firm can thus be induced to set a higher standard, namely through a higher "penalty" $\rho$, this becomes largely ineffective as the penalty increases and $q^{*}$ approaches $\bar{q}$.

Proposition 2 Suppose that it is optimal for the firm to implement a strictly positive standard $q^{*}>0$. Then the firm chooses $\eta=1$, while $q^{*}<\bar{q}$ satisfies

$$
-\left[p-f-\left(1-q^{*}\right) \rho\right] g\left(q^{*}\right)=\left[1-G\left(q^{*}\right)\right] \frac{d f}{d q^{*}},
$$

where $d f / d q^{*}>0$. An increase in $q^{*}$, as obtained from a higher "penalty" $\rho$, would thus be associated with a higher sales commission $f$.

Proof. We first show that $\eta=1$ is indeed uniquely optimal. This follows as a given $q^{*}>0$ can be implemented by a strictly smaller fee $f$ in case $\eta$ is chosen higher. Formally, we have from implicit differentiation of $\psi\left(q^{*}\right)=0$ in (10), which can be rewritten as

$$
f\left[\delta \mu \eta(2 \varphi-1) \int_{q^{*}}^{1}\left[q-q^{*}\right] g(q) d q-(1-\delta)\right]-c \delta r\left(q^{*}\right)=0,
$$

\footnotetext{
${ }^{10}$ Recall that replacing the present agent comes at zero cost.
} 
that $d f / d \eta<0$. Furthermore, that $d q^{*} / d \rho>0$ is obtained immediately from (13), after implicit differentiation and appealing to strict quasiconcavity of the objective function. Finally, note that the observation in the main text for $q^{*} \rightarrow \bar{q}$ follows immediately as in this case $d f / d q^{*} \rightarrow 0$ (cf. (6)). Q.E.D.

If the agent can be compensated only by $f$, instead of also some fixed wage as in IO (2007), then in equilibrium the relation between the size of the commission and the implemented standard is at first counterintuitive: A higher standard is associated with a higher sales commission. For policymakers, Proposition 2 thus spells out a warning against associating high fees with low standards. Moreover, Proposition 2 also reiterates a second key insight from this short paper: that the firm's internal agency problem may impose a limit on the standard that the firm can implement, even when policymakers choose an ever higher penalty $\rho$. The firm's ultimate response may then be rather to drop out of the market.

\section{References}

Basu, Amiya K., Rajiv Lal, V. Srinivasan, and Richard Staelin. 1985. "Salesforce Compensation Plans: An Agency Theoretic Perspective." Marketing Science, 4: $267-291$.

Bolton, Patrick, and Mathias Dewatripont. 2005. Contract Theory. Cambridge, MA: MIT Press.

Bolton, Patrick, Xavier Freixas, and Joel Shapiro. 2007. "Conflicts of Interest, Information Provision, and Competition in Banking." Journal of Financial Economics, 85: 297-330.

Darby, Michael R., and Edi Karni. 1973. "Free Competition and the Optimal Amount of Fraud." Journal of Law and Economics, 16: 67-88.

Dewatripont, Mathias, and Jean Tirole. 1999. "Advocates." Journal of Political Economy, 107: 1-39.

Holmström, Bengt, and Paul Milgrom. 1991. "Multitask Principal-Agent Analyses: Incentive Contracts, Asset Ownership, and Job Design." Journal of Law, Economics, 
and Organization, 7: 24-52.

Inderst, Roman, and Marco Ottaviani. 2007. "Misselling through Agents." Forthcoming American Economic Review.

Rajan, Ragu. 1992, "Insiders and Outsiders: The Choice between Informed and Arm's Length Debt.", Journal of Finance, 47: 1367-1399.

Shapiro, Carl, and Joseph Stiglitz. 1984, "Equilibrium Unemployment as a Worker Discipline Device." American Economic Review, 74: 433-444. 


\section{WORKING PAPERS}

1 (2006) Helmut Siekmann

$2(2006)$

3 (2006)

$4(2006)$

5 (2006)

$6(2006)$

7 (2006)

8 (2007)

9 (2007)

$10(2007)$
Helmut Siekmann

Helmut Siekmann

Reinhard H. Schmidt Aneta Hryckiewicz

Roman Inderst Holger M. Mueller

Felix Münnich

Roman Inderst Holger M. Mueller

Joachim Wieland

Helmut Siekmann

Henry Ordower

Helmut Siekmann
The Burden of an Ageing Society as a Public Debt (veröffentlicht in: European Public Law 2007 (13/3))

Die Unabhängigkeit von EZB und Bundesbank nach geltendem Recht und dem Vertrag über eine Verfassung für Europa

Die Verwendung des Gewinns der Europäischen Zentralbank und der Bundesbank

Financial Systems - Importance, Differences and Convergence

Financing A Portfolio of Projects

A Lender-Based Theory of Collateral

Staatsverschuldung als Herausforderung für die Finanzverfassung (veröffentlicht in: JZ 2006, S. 751 ff.)

Der Anspruch auf Herstellung von Transparenz im Hinblick auf die Kosten und Folgekosten der Steinkohlesubventionierung und den Börsengang der RAG AG

Demystifying Hedge Funds: A Design Primer (veröffentlicht in: UC Davis Business Law Journal 2007 (7/2), S. 323-372)

Die Spielbankabgabe und die Beteiligung der Gemeinden an ihrem Aufkommen - zugleich ein Beitrag zu den finanzverfassungsrechtlichen Ansprüchen der Gemeinden (veröffentlicht in: Organisation und Verfahren im sozialen Rechtsstaat, Festschrift für Friedrich E. Schnapp zum 
$11(2007)$

12 (2007)

$13(2007)$

14 (2007)

15 (2008)

16 (2008)

17 (2008)

18 (2008)

19 (2009)

20 (2009)
Symposium am

26.11.2007 in

Frankfurt am Main

Stefan Gerlach

Peter Kugler

Katrin Assenmacher-

Wesche

Stefan Gerlach

Toshitaka Sekine

Guntram B. Wolff

Helmut Siekmann

Katrin Assenmacher-

Wesche

Stefan Gerlach

Helmut Siekmann

Hans Genberg

Cho-Hoi Hui

Helmut Siekmann

Chun-Yu Ho

Wai-Yip Alex Ho
70. Geburtstag, Herausgegeben von Hermann Butzer, Markus Kaltenborn, Wolfgang Meyer, 2008, S.319-345)

Neuordnung der föderalen Finanzbeziehungen

Deflation and Relative Prices: Evidence from Japan and Hong Kong

Monetary Factors and Inflation in Japan

Schuldenanstieg und Haftungsausschluss im deutschen Föderalstaat: Zur Rolle des Moral Hazard

Föderalismuskommission II für eine zukunftsfähige Gestaltung der Finanzsystem nutzen

Ensuring Financial Stability: Financial Structure and the Impact of Monetary Policy on Asset Prices

Stellungnahme für die öffentliche Anhörung des Haushaltsausschusses zu dem Gesetzentwurf der Fraktion der SPD und Bündnis 90/Die Grünen für ein Gesetz zur Änderung der Hessischen Landeshaushaltsordnung

The credibility of The Link from the perspective of modern financial theory

Stellungnahme für die öffentliche Anhörung des Ausschusses für Wirtschaft, Mittelstand und Energie und des Haushalts- und Finanzausschusses des Landtags Nordrhein-Westfalen

Keine Hilfe für Banken ohne einen neuen

Ordnungsrahmen für die Finanzmärkte

On the Sustainability of Currency Boards:

Evidence from Argentina and Hong Kong 
21 (2009)

22 (2009)

23 (2009)

24 (2009)

25 (2009)

26 (2009)

27 (2009)

28 (2009)

29 (2009)

30 (2009)

31 (2009)

32 (2009)

33 (2009)

34 (2009)
Stefan Gerlach

Tim Oliver Berg

Melanie Döge

Stefan Jobst

Helmut Siekmann

Helmut Siekmann

Helmut Siekmann

Roman Inderst

Hasan Doluca

Roman Inderst

Ufuk Otag

Roman Inderst

Holger Müller

Roman Inderst Holger Müller

Roman Inderst Holger Müller

Roman Inderst

Roman Inderst Manuel Klein

Roman Inderst

Holger Müller

Felix Münnich
The Risk of Deflation

Cross-country evidence on the relation between equity prices and the current account

Aktienrecht zwischen börsen- und

kapitalmarktorientiertem Ansatz

Die Schaffung von Einrichtungen der Finanzaufsicht auf EU-Ebene

Stellungnahme zu dem Vorschlag der

Sachverständigengruppe unter dem Vorsitz von Jacques de Larosière

Die Neuordnung der Finanzmarktaufsicht

Stabilisierung der WestLB AG durch Garantien des Landes NRW

Stellungnahme für die öffentliche Anhörung des Haushalts- und Finanzausschusses des Landtags Nordrhein-Westfalen am 29. Oktober 2009

Loan Origination under Soft- and Hard-Information Lending

Bank Competition and Risk-Taking When Borrowers Care about Financial Prudence

CEO Replacement under Private Information

Early-Stage Financing and Firm Growth in New Industries

Bank capital structure and credit decisions

"Irresponsible Lending" with a better informed lender

Innovation, endogenous overinvestment, and incentive pay

Financing a Portfolio of Projects 

for Internal Compliance 